\title{
Elevated Cystine Levels in Cultured Skin Fibroblasts From Patients With I-Cell Disease
}

\author{
FRANK TIETZE AND JEAN DEBROHUN BUTLER
}

Laboratory of Biochemistry and Metabolism, National Institute of Arthritis, Metabolism, and Digestive Diseases (F. T.) National Institutes of Health and Section on Human Biochemical and Developmental Genetics (J. D. B.), National Institute of Child Health and Human Development, National Institutes of Health, Bethesda, Maryland USA

\section{Summary}

Cultured skin fibroblasts from patients with I-cell disease (mucolipidosis II) exhibit multiple deficiency of acid hydrolase activities associated with a defect in the mechanism of packaging of these enzymes into lysosomes. The authors have examined such cells to ascertain whether the impairment of lysosomal function is of so broad a nature as to result in the storage of the amino acid cystine in a manner similar to that seen in cells derived from patients with cystinosis, an unrelated lysosomal storage disease of unknown etiology. Of $10 \mathrm{I}$-cell lines examined by automated amino acid analysis, seven were found to possess abnormally high levels of total free cyst(e)ine (i.e., greater than $1 \mathrm{nmole} 1 / 2 \mathrm{Cys} / \mathrm{mg}$ protein). The mean half-cystine content of those I-cell lines subjected to multiple analysis ranged from 3-10 nmole/mg protein. levels which are comparable to those seen in homozygous cystinotic cells. The cystine content of several of these lines appeared to increase with subculture.

Cultured fibroblasts from two patients with the biochemically similar, but clinically less severe, mucolipidosis III (pseudo-Hurler polydystrophy) exhibited normal to marginally elevated levels of cystine, whereas cells from individuals with three different mucopolysaccharide storage disorders contained normal levels of the amino acid.

It was concluded that cystine, and not cysteine, was the predominant form of this amino acid in these cells because previous reaction of I-cell extracts with N-ethylmaleimide did not alter the observed cystine levels. The further identification of excess cystine in these cells was corroborated by analytical results obtained with a highly specific cystine-binding protein method as well as by highvoltage electrophoresis of extracts from cells pulsed with ${ }^{35} \mathrm{~S}$ cystine.

Comparative analysis of intracellular amino acids in normal and I-cell fibroblasts indicated that the elevation of cystine seen in the latter was unique to this amino acid and did not reflect a generalized increase in the total free amino acid content of these mutant cells.

\section{Speculation}

Cystinosis has been classified as a lysosomal storage disorder on the basis of cytologic and other evidence pointing to the intralysosomal localization of the stored cystine in cells from affected individuals. The fact that the principal enzyme function in lysosomes, viz., hydrolysis, is not known to play a role in the metabolic disposition of cystine sets this abnormality apart from the more typical lysosomal storage disorder and raises questions concerning the precise relation of lysosomal function to the pathogenesis of cystinosis. The present finding that I-cell fibroblasts, which are characterized by a broad spectrum of acid hydrolase deficiencies, also exhibit abnormally elevated cystine levels, appears to strengthen this relationship. However, further experiments will be necessary to determine whether the abnormal cystine levels in these two disorders arise from a common or related defect.
I-cell disease (mucolipidosis II [ML II]) is an inherited lysosomal disorder manifested in early infancy by a Hurler-like syndrome with predominating features of stunted growth, profound psychomotor disturbance, widespread skeletal deformities and death within the first decade $(15,19)$. Under the phase microscope, the cytoplasm of cultured skin fibroblasts from I-cell patients can be seen to be packed with opaque marble-like granules or inclusions-from which the disease derives its name (3)-which are believed to consist of lysosomes filled with a complex mixture of cellular macromolecules and membrane fragments (8). Consistent with this interpretation is the finding that such cells exhibit multiple acid hydrolase deficiencies when measured in vitro with a variety of synthetic $(14,15,26)$ or natural $(36)$ substrates. In contrast, the tissue culture medium in which the cells are grown (37), as well as the patient's plasma $(4,15,38)$ and other tissue fluids $(11,26,38)$ contain elevated amounts of several of these enzymes. Although the defective gene product responsible for these cellular anomalies is not precisely known, recent evidence $(9,10,12,22,30,32,35)$ has implicated the polysaccharide moiety of the lysosomal enzymes which may serve as recognition markers essential for the proper intracellular packaging of these glycoproteins.

Although the enzyme deficiencies thus far reported in I-cell fibroblasts have been those associated primarily with hydrolysis of carbohydrate linkages, there is little reason to suppose that lysosmal activities toward other classes of substrates might not be similarly affected; if so, the resulting catabolic defect(s) might well result in the abnormal intralysosomal accumulation of a wide variety of degradative intermediates whose molecular size would not permit their penetration of the lysosomal membrane. With this consideration in mind, it was thought to be of interest to determine whether cultured I-cells would be found to exhibit the excessive intracellular accumulation of free cystine similar to that noted in cystinosis, an unrelated storage disorder of uncertain etiology $(23,24)$.

Although previous investigations have indicated that the excess stores of cystine in isolated or cultured cells from cystinotic patients are sequestered within lysosomes $(23,24)$, evidence is presently lacking which would relate such storage to a specific lysosomal defect. It is reported here that a high proportion of cultured fibroblast strains from patients with mucolipidosis II possesses abnormally high levels of free cystine. Parallel data on cystine levels in fibroblasts from patients with the biochemically similar, but clinically less severe, mucolipidosis III (pseudo-Hurler polydystrophy) $(13,29)$, as well as from patients with several mucopolysaccharide storage disorders, are also presented. A preliminary report of this work has appeared (33).

\section{MATERIALS AND METHODS}

\section{REAGENTS}

$\mathrm{N}$-Ethylmaleimide and the reduced and oxidized forms of glutathione (GSH and GSSG, respectively) were purchased from 
Calbiochem. Cysteine (CySH) and cystine (CySSCy) were products of ICN Pharmaceuticals, Inc. (Life Sciences Group). Sulfosalicylic acid was obtained from Fisher Scientific Company. All substrates for use in lysosomal enzyme assays (P-nitrophenyl phosphate, P-nitrocatechol sulfate, and the P-nitrophenyl derivatives of $\beta$-D-galactose, $\beta$-D-glucuronic acid and $N$-acetyl- $\beta$-D-glucosamine) were obtained from Sigma Chemical Company. The $\mathrm{N}$-ethylmaleimide adducts of $\mathrm{CySH}$ and GSH were prepared by reacting the thiols for several hr at room temperature with a twofold excess of the reagent in dilute phosphate buffer, $\mathrm{pH} \mathrm{7;} \mathrm{the}$ resulting solutions were used as such for marker purposes in electrophoretic runs. ${ }^{35} \mathrm{~S}$-cystine $(100-200 \mathrm{mCi} / \mathrm{mmole})$ was obtained from Amersham/Searle Corp. (Cat. No. SJ 126); the material, ca. $500 \mu \mathrm{Ci}$ total, was dissolved in $1.0 \mathrm{ml} 0.1 \mathrm{~N} \mathrm{HCl}$ and stored at $-25^{\circ}$. The addition of this stock solution to tissue culture medium was always accompanied by an equivalent amount of $\mathrm{NaHCO}_{3}$ to neutralize the $\mathrm{HCl}$.

\section{CELL LINES}

The majority of the I-cell fibroblast lines employed in this investigation as well as lines from patients with mucolipidosis III (ML III) and several mucopolysaccharide storage disorders were generously provided by Dr. Elizabeth F. Neufeld, (Bethesda, MD). I-cell and other lines designated by the prefix $G M$ originated from the Human Genetic Mutant Cell Repository, Camden, NJ. Two additional strains from patients with mucolipidosis II (ML II lines 9 and 10) were obtained through the courtesy of Dr. Ulrich Wiesmann (Berne, Switzerland). Fibroblast lines from patients with cystinosis were obtained from the collection of Dr. Joseph D. Schulman (Bethesda, MD) and from the Mutant Cell Repository. Normal control lines were secured from several of the above sources and from the American Type Culture Collection (Rockville, MD).

\section{CELL CULTURE}

Fibroblast cultures, originated from skin biopsies, were grown in $250 \mathrm{ml}$ plastic flasks containing $20 \mathrm{ml}$ Eagle's Minimal Essential Medium supplemented with nonessential amino acids, $10 \%$ fetal calf serum (Grand Island Biological Co.) and antibiotics under conditions similar to those described by Hall et al. (7). The cystine content of the culture medium was $24 \mathrm{mg} /$ liter. Cells were subcultured as needed at intervals ranging from 2-8 wk.

\section{PREPARATION OF PROTEIN-FREE CELL EXTRACTS}

Cell cultures to be analyzed for cystine content were always fed within 2 days before workup in order to minimize the possibility of nutritional depletion of medium cystine. Cell monolayers in $250 \mathrm{ml}$ culture flasks or $100 \mathrm{~mm}$ plastic dishes were washed four times with $10 \mathrm{ml}$ physiologic saline, treated for $15 \mathrm{~min}$ at $37^{\circ}$ with $10 \mathrm{ml} 0.25 \%$ trypsin (Grand Island Biological Co.) and the liberated cells washed with saline three more times by centrifugation. All washings were carried out at room temperature. The cell pellet was treated with $0.5-1.0 \mathrm{ml} 2 \%$ sulfosalicylic acid and the suspension maintained on ice for several hr or overnight at $-25^{\wedge}$ before centrifugation. In those experiments involving blockage of cellular thiols with $\mathrm{N}$-ethylmaleimide the washed cells were suspended in $0.5-1.0 \mathrm{ml} 10 \mathrm{mM}$ phosphate buffer, $\mathrm{pH} 7.0$, containing $10 \mathrm{mM}$ thiol reagent and disrupted by sonication in a Branson Sonifier (Heat Systems Ultrasonics, Inc., Model W140); after treatment with $\mathrm{N}$-ethylmaleimide, the cell suspensions were brought to $2 \%$ sulfosalicylic acid by appropriate addition of the concentrated protein reagent. Protein content of the resulting pellets was determined by the method of Lowry et al. (18) after dissolution of the cell pellet in warm $0.5 \mathrm{~N} \mathrm{NaOH}$.

\section{CYSTINE ANALYSIS}

Initial cystine analyses were performed with a Beckman Model $120 \mathrm{C}$ amino acid analyzer (41). Because of the limited sensitivity of this instrument, particularly with respect to cyst(e)ine levels in normal cells, the majority of the analyses reported here was carried out with the same manufacturer's considerably more sensitive Model 121M instrument (41). Cystine contents of cell supernatants were also determined by the $E$. coli cystine-binding protein assay of Oshima et al. $(21,42)$. In conformity with previous practice, results of cystine or total cyst(e)ine analyses are expressed as nanomoles half-cystine per mg protein.

\section{LABELING EXPERIMENTS}

Confluent cell cultures in $100 \mathrm{~mm}$ dishes were washed once with sterile saline and incubated $48 \mathrm{hr}$ with $10 \mathrm{ml}$ Eagle's medium containing 10-20 $\mu \mathrm{Ci}{ }^{35} \mathrm{~S}$-cystine. Protein-free extracts were prepared from the washed cells by treatment with sulfosalicylic acid as described previously.

\section{HIGH-VOLTAGE ELECTROPHORESIS}

The protein-free supernatant fraction of cells labeled with ${ }^{35} \mathrm{~S}$ cystine as described previously was spotted on Whatman $3 \mathrm{MM}$ sheets and subjected to high-voltage electrophoresis in $7.4 \%$ formic acid in a Gilson Model D Electrophorator. Runs were routinely carried out for $90 \mathrm{~min}$ at $3.5-4.0 \mathrm{kv}$. Appropriate unlabeled amino acid or glutathione standards, 40 nmole each, were spotted and run at the same time. After drying, the radioactive columns were cut into $1 \frac{1 / 2}{2}$ inch wide strips which were further divided transversely into $1 / 4$-inch segments, each of which was placed in a counting vial containing $5 \mathrm{ml}$ scintillation fluid (New England Nuclear "Econofluor") and counted in a Beckman Model LS 233 counter. Radioactive peaks were identified by comparison with unlabeled standards visualized by staining with $0.25 \%$ ninhydrin in acetone.

\section{LYSOSOMAL ENZYME ASSAYS}

Measurement of acid hydrolase activities was carried out on fibroblast lysates prepared as follows. To the washed, trypsinized cell pellet in a $12 \mathrm{ml}$ glass centrifuge tube was added $1 \mathrm{ml}$ cold distilled water and the mixture subjected to four 15-sec bursts in the sonifier at $0^{\circ}$ (instrument setting 4) using a microtip probe. Procedures for the determination of acid phosphatase, $\beta$-galactosidase, $\beta$-glucuronidase, $\beta$-hexosaminidase, and arylsufatase- $A$ employed the appropriate P-nitrophenyl or P-nitrocatechol substrates in accordance with the protocols of Hall et al. $(7,40)$.

\section{RESULTS}

Results of measurements of acid hydrolase activities in cell lysates from eight ML II and two ML III lines are recorded in Table 1. All of these cell lines showed significant depression of one or more of the measured activities relative to the average control values with the exception of acid phosphatase; in agreement with previous reports $(14,15,26)$, acid phosphatase was either normal or somewhat elevated in all cases.

Table 2 summarizes the results of cystine analyses carried out on all the normal and mutant cell lines used in this investigation. Multiple analyses of six ML II lines (Nos. 1-6) gave mean values of half-cystine levels considerably greater than those of the normal controls, and, in some cases, similar in magnitude to those measured in frankly cystinotic cells. Only one analysis was carried out for each of the ML II strains 7 and 8; of these, the first showed a half-cystine level greater than $2 \mathrm{nmole} / \mathrm{mg}$ protein, whereas the second was only marginally elevated. Two additional ML II lines (Nos. 9 and 10) exhibited essentially normal levels of cystine. Two lines from patients with mucolipidosis III were available for analysis; one of these (No. 1) appeared entirely normal with respect to its cystine content, whereas the second, GM 113, showed a tendency toward marginally elevated levels. Cultures from patients with three distinct mucopolysaccharide storage disorders (Hurler, Hurler/Scheie, and Hunter syndromes) possessed normal cystine contents (MPS, Table 2). Half-cystine levels for five cystinotic lines are also recorded; as expected, the mean levels obtained with these cells were grossly elevated, approaching or exceeding $10 \mathrm{nmole} / \mathrm{mg}$ protein in every case. 
Table 1. Lysosomal enzyme activities in normal and mutant fibroblasts

\begin{tabular}{|c|c|c|c|c|c|c|}
\hline \multirow[b]{2}{*}{ Genotype } & \multirow{2}{*}{$\begin{array}{c}\text { Cell }^{2} \\
\text { line } \\
\text { no. }\end{array}$} & \multicolumn{5}{|c|}{ Acid Hydrolase activity ${ }^{1}$} \\
\hline & & $\begin{array}{c}\text { Acid } \\
\text { phosphatase }^{3}\end{array}$ & $\beta$-Glucuronidase ${ }^{3}$ & $\beta$-Galactosidase ${ }^{3}$ & Hexoseaminidase $^{3}$ & Arylsulfatase- $\mathrm{A}^{4}$ \\
\hline Normal $^{5}$ & & $1.69-4.89$ & $0.23-0.79$ & $0.34-0.87$ & $6.49-10.77$ & $0.28-0.75$ \\
\hline$(N=5)$ & & [3.05] & [0.49] & {$[0.66]$} & [8.88] & {$[0.47]$} \\
\hline \multirow[t]{8}{*}{ ML II } & 1 & $3.10(102)$ & $0.065(13)$ & $0.038(6)$ & $1.56(18)$ & $0.052(11)$ \\
\hline & 2 & $7.4(243)$ & $0.058(12)$ & $0.022(3)$ & $0.89(10)$ & $0.035(7)$ \\
\hline & 3 & $2.93(96)$ & $0.23(47)$ & $0.055(8)$ & $2.04(23)$ & $0.21(45)$ \\
\hline & 4 & $6.0(197)$ & $0.017(3)$ & $0.015(2)$ & $0.87(10)$ & $0.057(12)$ \\
\hline & 5 & $3.3(108)$ & $0.16(32)$ & $0.044(7)$ & $1.83(21)$ & $0.049(10)$ \\
\hline & 6 & & & & $0.84(9)$ & \\
\hline & 9 & $2.68(88)$ & $0.11(22)$ & $0.041(6)$ & $1.79(20)$ & $0.049(10)$ \\
\hline & 10 & $3.80(125)$ & $0.069(14)$ & $0.034(5)$ & $1.37(15)$ & $0.060(13)$ \\
\hline \multirow[t]{2}{*}{ ML III } & 1 & $2.88(94)$ & $0.16(33)$ & $0.15(23)$ & & $0.054(11)$ \\
\hline & 2 & $2.22(93)$ & $0.064(13)$ & $0.19(29)$ & $2.47(28)$ & $0.10(21)$ \\
\hline
\end{tabular}

${ }^{1}$ Figures in parentheses are percent of normal mean.

${ }^{2}$ These cell line numbers correspond to those shown in Table 2.

${ }^{3}$ Micromoles P-nitrophenol liberated per hour per mg protein at $37^{\circ}$.

${ }^{4}$ Micromoles P-nitrocatechol liberated per hour per $\mathrm{mg}$ protein at $37^{\circ}$.

${ }^{5}$ Figures in brackets represent mean normal values.

Table 2. Cystine content of normal and mutant fibroblasts

\begin{tabular}{|c|c|c|c|c|}
\hline \multirow[b]{2}{*}{ Genotype } & \multirow[b]{2}{*}{ Cell line no. } & \multirow{2}{*}{$\begin{array}{l}\text { No. of } \\
\text { assays }\end{array}$} & \multicolumn{2}{|c|}{$\begin{array}{l}\text { Cystine content } \\
\text { (nanomoles } 1 / 2 \text { cystine/mg protein) }\end{array}$} \\
\hline & & & Range & Mean \pm SD \\
\hline \multirow[t]{9}{*}{ Normal } & $1(\mathrm{GM} \mathrm{105)}$ & 9 & $0.052-0.50$ & $0.20 \pm 0.13$ \\
\hline & 2 & 8 & $0.0-0.57$ & $0.27 \pm 0.17$ \\
\hline & 3 & 5 & $0.082-0.51$ & $0.27 \pm 0.16$ \\
\hline & 4 & 2 & $0.17-0.24$ & $0.21 \pm 0.05$ \\
\hline & 5 & 2 & $0.42-0.55$ & $0.49 \pm 0.09$ \\
\hline & 6 & 1 & 0.39 & \\
\hline & 7 & 1 & 0.10 & \\
\hline & 8 (GM 497) & 1 & 0.19 & ' \\
\hline & 9 (GM 969) & 1 & 0.22 & \\
\hline \multirow[t]{10}{*}{ MLII } & 1 & 14 & $4.3-34.0$ & $12.04 \pm 9.73$ \\
\hline & 2 & 6 & $1.6-9.46$ & $3.84 \pm 3.17$ \\
\hline & 3 & 10 & $1.47-4.59$ & $3.10 \pm 1.04$ \\
\hline & $4(\mathrm{GM} \mathrm{164)}$ & 6 & $0.98-11.85$ & $4.49 \pm 4.99$ \\
\hline & $5(\mathrm{GM} 1586)$ & 6 & $0.66-6.21$ & $3.84 \pm 2.28$ \\
\hline & 6 (GM 1423) & 2 & $4.15-4.44$ & $4.30 \pm 0.21$ \\
\hline & 7 & 1 & 2.22 & \\
\hline & 8 & 1 & 0.85 & \\
\hline & 9 & 4 & $0.12-0.55$ & $0.37 \pm 0.18$ \\
\hline & 10 & 3 & $0.20-0.46$ & $0.32 \pm 0.13$ \\
\hline \multirow[t]{2}{*}{ ML III } & 1 & 5 & $0.0-0.40$ & $0.09 \pm 0.17$ \\
\hline & $2(\mathrm{GM} 113)^{1}$ & 4 & $0.58-1.17$ & $0.91 \pm 0.26$ \\
\hline MPS $^{2}$ (Hurler) & 1 (GM 1391) & 3 & $0.27-0.53$ & $0.39 \pm 0.13$ \\
\hline MPS (Hurler-Scheie) & $2(\mathrm{Gm} \mathrm{963)}$ & 2 & $0.19-0.35$ & $0.27 \pm 0.11$ \\
\hline MPS (Hunter) & 3 & 2 & $0.33-0.74$ & $0.54 \pm 0.29$ \\
\hline \multirow[t]{5}{*}{ Cystinosis } & 1 & 8 & $5.81-25.5$ & $17.2 \pm 6.85$ \\
\hline & 2 (GM 8) & 1 & 30.8 & \\
\hline & 3 (GM 67) & 1 & 30.6 & \\
\hline & $4^{3}$ & 1 & 12.7 & \\
\hline & 5 & 1 & 9.41 & \\
\hline
\end{tabular}

' Classification uncertain; see the Discussion.

${ }^{2}$ MPS-mucopolysaccharidosis.

${ }^{3}$ Intermediate (late-onset) type; other cystinotic lines are from infantile nephropathic patients.

It is evident from the data presented in Table 2 that the observed cystine levels in several of the ML II strains are spread over a considerable range of values. Among the possible experimental variables which were considered in relation to this phenomenon, the most significant appeared to be the age or passage number of the cell culture. This is evident when the data for three of the ML II lines (Nos. 1, 2, and 4) are represented as shown in Figure 1, where the age of the culture has been expressed in terms of the time interval after the first cystine analysis. It should be noted that the data points depicted in this figure do not necessarily correspond to successive passage numbers; in the case of ML II line No. 4 , for example, a considerable number of passages intervened between the second and third time points shown.

The data shown in Table 2 refer, in almost all instances, to the 
total free cyst(e)ine content of the cells (i.e., CySH + CySSCy) inasmuch as the protein-free extracts were prepared by direct treatment of the washed cells with aqueous sulfosalicylic acid. In order to ascertain which form of the amino acid was predominant in those I-cells with elevated cystine levels, comparative analyses were carried out on protein-free supernatants prepared from cells disrupted in the presence and absence of $\mathrm{N}$-ethylmaleimide, which forms a stable derivative with cysteine. As seen in Table 3, disruption of cells in the presence of $10 \mathrm{mM}$ N-ethylmaleimide had little or no effect on the half-cystine content of ML II lines 1 and 3 , indicating that the predominant form of the amino acid in these cells was cystine.

In order to establish with greater certainty the identity of the ninhydrin-positive component in I-cell supernatants moving as cystine on the ion-exchange column, sulfosalicylic acid extracts from cells prepared in the absence (Exp. 1) or presence (Exp. 2) of $\mathrm{N}$-ethylmaleimide were assayed by the cystine-binding protein method of Oshima et al. (21) and the results compared with those obtained on the same samples by automated amino acid analysis

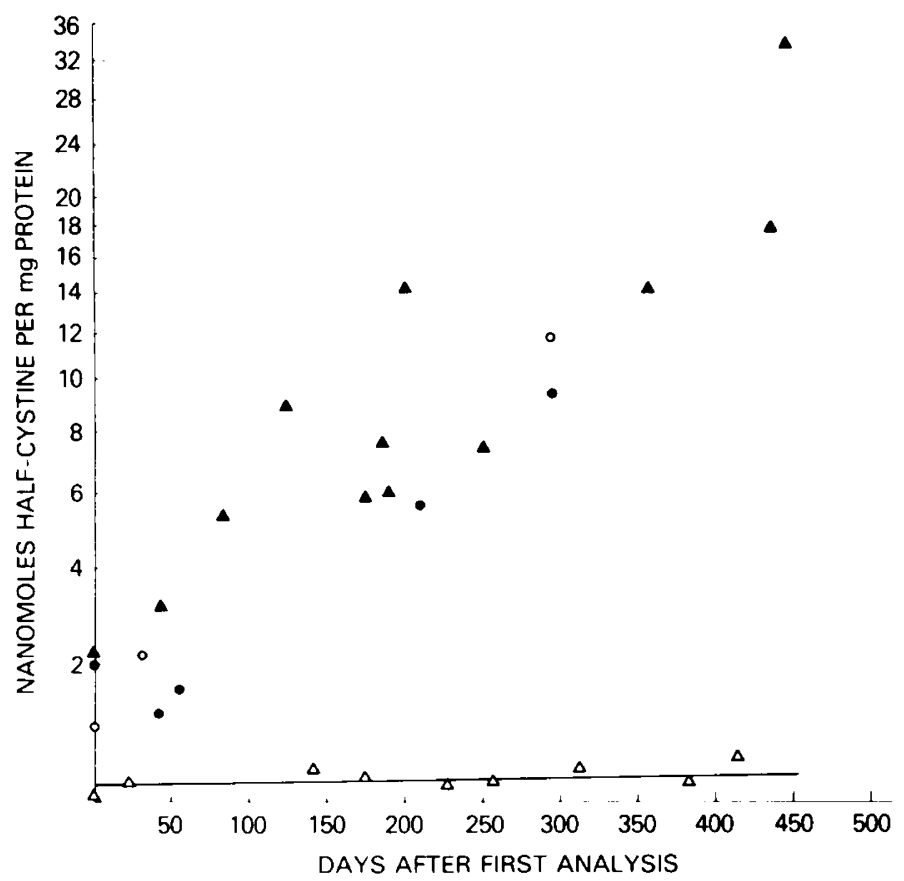

Fig. 1. Dependence of cystine levels in ML II cells on age of culture. Cell lines, continuously subcultured at 2- to 8-wk intervals throughout the indicated period, originated from secondary cultures whose initial cystine analyses are shown at the arbitrarily designated zero time. The total number of passages depicted in these experiments ranged from approximately 15 to 25 . Legend: Normal cells (GM 105) $-\triangle-\Delta-$, ML II cells $\Delta-\Delta-$ ML II line No. 1, -๑- ML II line No. 2, - - - ML II line No.

Table 3. Comparative cystine contents of I-cell fibroblasts disrupted in the presence and absence of $N$-ethylmaleimide ${ }^{1}$

\begin{tabular}{cccc}
$\begin{array}{c}\text { Exp. } \\
\text { no. }\end{array}$ & $\begin{array}{c}\text { ML II } \\
\text { line no. }\end{array}$ & $\begin{array}{c}\text { N-ethyl- } \\
\text { maleimide }\end{array}$ & $\begin{array}{c}\text { nmoles } 1 / 2 \\
\text { cystine/mg } \\
\text { protein }\end{array}$ \\
\hline 1 & 1 & - & 5.8 \\
& 3 & + & 6.0 \\
2 & 3 & - & 1.9 \\
& & + & 2.6 \\
\hline
\end{tabular}

' Pooled, washed cells were divided into equal portions, one of which was treated directly with sulfosalicylic acid. The second portion was sonicated in $10 \mathrm{mM} \mathrm{N}$-ethylmaleimide before treatment with sulfosalicylic acid. Total cyst(e)ine contents in the supernatant fractions were determined by automated amino acid analysis.

${ }^{2}$ These cell lines correspond to those shown in Table 2.
Table 4. Comparative half-cystine levels in normal and mutant fibroblasts determined by automated amino acid analysis and by cystine-binding protein assay

\begin{tabular}{|c|c|c|c|c|}
\hline \multirow[b]{2}{*}{ Exp. } & \multirow[b]{2}{*}{ Genotype } & \multirow{2}{*}{$\begin{array}{c}\text { Cell } \\
\text { line no. }\end{array}$} & \multicolumn{2}{|c|}{$\begin{array}{l}\text { Cystine content (nmoles } \\
\text { cystine/mg protein) }\end{array}$} \\
\hline & & & $121 \mathrm{M}$ & CBP \\
\hline \multirow[t]{7}{*}{1} & Normal & 1 & 0.19 & 0.23 \\
\hline & & 2 & 0.30 & 0.34 \\
\hline & ML II & 1 & 3.17 & 2.72 \\
\hline & & 3 & 1.79 & 1.30 \\
\hline & & 9 & 0.21 & 0.46 \\
\hline & ML III & 1 & 0.21 & 0.47 \\
\hline & & 2 & 0.37 & 0.94 \\
\hline \multirow[t]{8}{*}{2} & Normal & 1 & 0.11 & 0.27 \\
\hline & & 2 & 0.11 & 0.31 \\
\hline & ML II & 1 & 14.30 & 16.2 \\
\hline & & 2 & 2.07 & 3.51 \\
\hline & & 3 & 3.60 & 5.58 \\
\hline & & 4 & 1.32 & 2.62 \\
\hline & MPS $^{3}$ & 2 & 0.12 & 0.25 \\
\hline & & 3 & 0.39 & 0.27 \\
\hline
\end{tabular}

${ }^{1}$ Supernatant fractions prepared from cells disrupted in the absence (Exp. 1) or presence (Exp. 2) of N-ethylmaleimide were analyzed for cystine by ion-exchange chromatography on the Beckman Model $121 \mathrm{M}$ analyzer and by the cystine-binding protein (CBP) method of Oshima $e t$ al. (21).

${ }^{2}$ Cell line numbers correspond to those shown in Table 2.

${ }^{3}$ MPS-mucopolysaccharidosis.

Table 5. Intracellular amino acids in normal and $M L I I$ fibroblasts ${ }^{1}$

\begin{tabular}{lccc}
\hline & & \multicolumn{2}{c}{ ML II cell line no. ${ }^{2}$} \\
\cline { 3 - 4 } \multicolumn{1}{c}{ Amino acid } & Mormal $(N=3)$ & 1 & 3 \\
\hline Aspartic & $5.1(2.6-7.0)$ & 7.5 & 6.3 \\
Threonine & $2.2(2.1-2.5)$ & 6.5 & 3.9 \\
Serine & $2.4(2.1-2.8)$ & 6.8 & 4.4 \\
Proline & $3.8(3.4-4.2)$ & 5.0 & 2.3 \\
Glycine & $5.4(4.5-7.2)$ & 7.4 & 3.9 \\
Alanine & $4.0(3.3-4.9)$ & 6.3 & 3.4 \\
Valine & $1.5(1.1-2.1)$ & 3.3 & 2.0 \\
1/2 Cystine & N.M. & 6.8 & 4.2 \\
Methionine & $2.6(0.70-4.6)$ & 2.3 & 1.2 \\
Isoleucine & $0.80(0.62-1.1)$ & 2.6 & 0.44 \\
Leucine & $2.0(1.7-2.5)$ & 4.1 & 2.1 \\
Tyrosine & $1.4(1.2-1.6)$ & 2.7 & 1.3 \\
Phenylalanine & $0.63(0.42-0.90)$ & 1.4 & 0.65 \\
Lysine & $3.6(1.5-2.0)$ & 3.6 & 4.9 \\
Histidine & $1.8(1.5-2.0)$ & 1.5 & 1.6 \\
Arginine & $4.0(3.5-4.4)$ & 2.8 & 3.6 \\
\hline I & &
\end{tabular}

${ }^{1}$ Sulfosalicylic acid supernatant fractions were prepared as described in Materials and Methods and subjected to amino acid analysis on a Beckman Model $121 \mathrm{M}$ analyzer. Results are expressed as nanomoles per mg protein.

${ }^{2}$ ML II cell line numbers 1 and 3 correspond to those shown in Table 2.

${ }^{3}$ N.M.-not measurable at the instrumental sensitivity employed in these analyses.

(Table 4). The generally satisfactory agreement of the results of the two methods of analysis further served to establish the identity of the component in question as cystine.

That the elevation of cystine seen in our I-cell lines was unique to this amino acid and did not merely reflect a generalized increase in the amino acid content of these cells was indicated when protein-free lysates of three normal and two ML II lines showing excess cystine levels were analyzed for total free amino acid content. From the analytical results shown in Table 5, it is evident that, with the exception of cystine the general level of free amino 

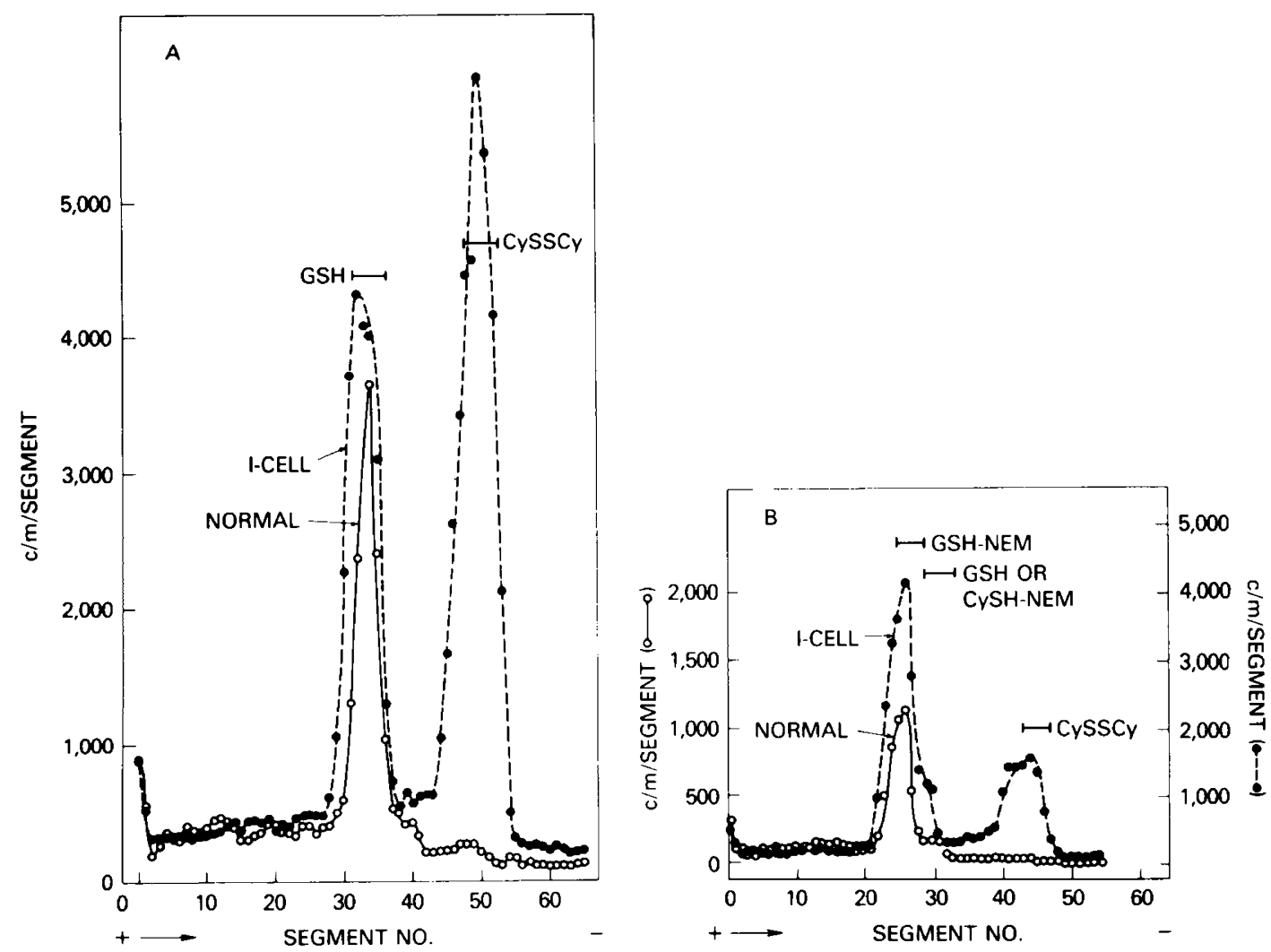

Fig. 2. Electrophoretograms of sulfosalicyclic acid extracts of normal and I-cell fibroblasts (ML II cell line No. 1) incubated 48 hr in the presence of ${ }^{35}$ S-cystine. After electrophoresis, appropriate strips $1-1 / 2$ inches wide were cut transversely into $1 / 4$-inch segments and counted by liquid scintillation as described in Materials and Methods. A: Cells disrupted in sulfosalicyclic acid without previous treatment with N-ethylmaleimide. $B$ : Cells disrupted by sonication in $10 \mathrm{mM} \mathrm{N}$-ethylmaleimide before treatment with sulfosalicyclic acid. Positions of unlabeled standards, run concurrently, are indicated by the horizontal line segments. GSH and the N-ethylmaleimide derivative of cysteine are not separable under these conditions. The experiments shown in $A$ and $B$ were carried out at different times. NEM: N-ethylmaleimide.

acids in the two ML II lines (Nos. 1 and 3) exhibiting increased cystine content was not strikingly different from the mean values found in normal cells.

In Figure 2 are shown patterns of radioactivity after high voltage electrophoresis of protein-free extracts from normal and ML II fibroblasts incubated for $48 \mathrm{hr}$ with ${ }^{35} \mathrm{~S}$-cystine. Within the mobility region of interest, normal cells show essentially a single peak of radioactivity corresponding to the position of GSH (Fig. $2 \mathrm{~A}$ ) or its $\mathrm{N}$-ethylmaleimide derivative (Fig. 2B); little or no radioactivity is detectable in the area corresponding to the position of cystine in the normal extracts. In contrast to the patterns seen in normal cells, those obtained with ML II cell line No. 1 showed an additional and prominent cystine peak, in agreement with the results of amino acid analyses. Results similar to the previously mentioned (not shown here) were obtained with ML II cell line No. 3. The observation that labeled cystine constituted the most prominent nonGSH peak in electrophoretograms from ML II cells treated with N-ethylmaleimide (Fig. 2B), as well as from those not so treated (Fig. 2A), is additional evidence that it is cystine, and not cysteine, that is the predominant form of this amino acid in these cells.

\section{DISCUSSION}

Seven of ten I-cell lines examined during the course of this investigation were consistently found to possess abnormally high levels of cystine (i.e., $>1$ nmole $1 / 2$ cystine $/ \mathrm{mg}$ protein). The mean contents of those lines subjected to multiple analyses ranged from 3-10 nmole/mg, levels which are comparable to those seen in cystinotic cells (23).

As noted previously (Fig. 1), the cystine content of several of the I-cell lines appeared to increase with subculture, ultimately attaining, in the case of ML II line No. 1, the extraordinarily high level of 34 nmoles half-cystine per mg protein (Table 2). Whether this phenomenon reflects a continually increasing storage of cystine throughout the life span of these cells or is due to the increasing inability of the cells to metabolize the amino acid through an accumulation of errors in cell structure or function is not presently known. The observation that the cystine content of I-cells may increase with age or passage number calls to mind the earlier comment of DeMars and Leroy (3) that the number of inclusion bodies seen in these cells appears to increase with generation number. A similar trend toward higher cystine content with passage number has been observed in cystinotic fibroblasts by Crawhall et al. (2).

The finding of distinctly normal levels of cystine in ML II lines 9 and 10 is perhaps not surprising in view of the known heterogeneity in clinical and biochemical features of this disease $(5,6$, 16). In this connection, it is noteworthy that ML II line 9 was derived from a patient diagnosed with I-cell disease (39), but whose clinical course seems somewhat milder than usual; although presenting the characteristic features of type II mucolipidosis the patient has presently attained the age of nine years and continues to develop mentally and physically (private communication from Dr. Ulrich N. Wiesmann). On the other hand, ML II line No. 10 was from a patient who appeared to be a typical type II (Dr. Ulrich $\mathrm{N}$. Wiesmann, private communication).

In contrast with the results obtained in ML II cells, the two lines from individuals with mucolipidosis III exhibited in one case (ML III line No. 1) normal, and in the second case (GM 113), marginally elevated levels of cystine. However, some uncertainty may surround the classification of the second line. Although originally listed as ML II, GM 113 has been reclassified as ML III in the current catalog (4th Edition) of the Human Genetic Mutant Cell Repository, apparently on the basis of its minimally depressed levels of lysosomal enzyme activities (private communication from 
Dr. Arthur E. Greene ); further information concerning the clinical status of this patient was not available to us. ML III line No. 1, on the other hand, was derived from an adult male patient whose clinical and biochemical history has been well documented $(1,29)$. Cultured fibroblasts from type III patients are known to resemble closely those of type II in showing the phase-positive inclusions and multiple acid hydrolase deficiencies characteristic of the latter $(1,13,31)$. However, the clinical course in mucolipidosis III is of a milder nature, with frequent survival to adulthood. Whether, as appears to be suggested by our results, the cystine content of cultured cells from mucolipidosis patients may be a useful concomitant in the differential diagnosis of these two clinical types cannot presently be assessed until further studies with additional lines have been carried out.

Although cystinosis is classified as a lysosomal storage disorder on the basis of experimental evidence relating to the intracellular localization of the sequestered cystine (23), its underlying basis remains obscure. Unlike other substances stored in lysosomes in abnormal quantities as a result of specific defects in acid hydrolase activities (20), cystine is not known to be susceptible to enzymic hydrolytic cleavage, nor is its major degradative pathway considered to involve lysosomal enzymes (27). For this reason, other mechanisms involving blockage along the known (nonlysosomal) metabolic pathway of cystine (17) or impairment in its exit through the lysosomal membrane (25) have been considered along with other possibilities $(28,34)$, as causative factors in cystinosis. The observation that I-cells can display pseudocystinotic characteristics may have implications for the pathogenesis of cystinosis in that it is compatible with the notion that lysosomes or lysosomal components may constitute functionally important elements in the intracellular disposition of cystine and that disturbances in their function can lead to its excessive accumulation therein.

\section{REFERENCES AND NOTES}

1. Berman, E. R., Kohn, G., Yatziv, S., and Stein, H.: Acid hydrolase deficiencies and abnormal glycoproteins in mucolipidosis III (pseudo-Hurler polydystrophy). Clin. Chim. Acta, 52: 115 (1974).

2. Crawhall, J. C., Oshima, R. G., and Schneider, J. A.: Factors controlling the non-protein cystine content of cystinotic fibroblasts. Pediatr. Res., 11: 41 (1977)

3. De Mars, R., and Leroy, J. G.: The remarkable cells cultured from a human with Hurler's syndrome: an approach to visual selection for in vitro genetic studies. In Vitro, 2: 107 (1966).

4. Den Tandt, W. R., Lassila, E., and Phillippart, M.: Leroy's I-cell disease markedly increased activity of plasma hydrolases. J. Lab. Clin. Med., 83: 403 (1974)

5. Gilbert, E. F., Dawson, G., Zu Rhein, G. M., Opitz, J. M., and Spranger, J. W.: I-cell disease, mucolipidosis II: pathological, histochemical, ultrastructural, and biochemical observations in four cases. Z. Kinderheilk., 114: 259 (1973).

6. Glaser, J. H., McAlister, W. H., and Sly, W. S.: Genetic heterogeneity in multiple lysosomal hydrolase deficiency. J. Pediatr., 85: 192 (1974).

7. Hall, C. W., Liebaers, I., Di Natale, P., and Neufeld, E. F.: Enzymatic diagnosis of the genetic mucopolysaccharide storage disorders. In: V. Ginsburg: Advances in Enzymology (Complex Carbohydrates [Part C]) Vol. 50, p. 439 (Academic Press, New York, 1978).

8. Hanai, J., Leroy, J. and O'Brien, J. S.: Ultrastructure of cultured fibroblasts in Icell disease. Am. J. Dis. Child., 122: 34 (1971)

9. Hickman, S., and Neufeld, E. F.: A hypothesis for I-cell disease: defective hydrolases that do not enter lysosomes. Biochem. Biophys. Res. Commun., 49: 992 (1972)

10. Hickman, S., Shapiro, L. J., and Neufeld, E. F.: A recognition marker required for uptake of a lysosomal enzyme by cultured fibroblasts. Biochem. Biophys. Res. Commun., 57: 55 (1974).

11. Huijing, F., Warren, R. J., and McLeod, A. G. W.: Elevated activity of lysosomal enzymes in amniotic fluid of a fetus with mucolipidosis II (I-cell disease). Clin. Chim. Acta, 44: 453 (1973).

12. Kaplan, A., Achord, D. T., and Sly, W. S.: Phosphohexosyl components of a lysosomal enzyme are recognized by pinocytosis receptors on human fibroblasts. Proc. Natl. Acad. Sci. USA, 74: 2026 (1977).

13. Kelly, T. E., Thomas, G. H., Taylor, H. A., McKusick, V. A., Sly, W. S., Glaser, J. H., Robinow, M., Luzzatti, L., Espiritu, C., Feingold, M., Bull, M. J., Ashenhurst, E. M., and Ives, E. J.: Mucolipidosis III (pseudo-Hurler polydystrophy): clinical and laboratory studies in a series of 12 patients. Johns Hopkins Med. J.. 137: 156 (1975).
14. Leroy, J. G., Ho, M. W., MacBrinn, M. C., Zielke, K., Jacob, J., and O'Brien, J. S.: I-cell disease: Biochemical studies. Pediatr. Res., 6: 752 (1972)

15. Leroy, J. G., and Martin, J. J.: Mucolipidosis II (I-cell disease): Present state of knowledge. Birth Defects, 11 (No. 6): 283 (1975).

16. Leroy, J. G., Spranger, J. W., Feingold, M., Opitz, J. M., and Crocker, A. C.: Icell disease: A clinical picture. J. Pediatr., 79: 360 (1971).

17. Linneweh, F., Schaumlöffel, E., Graul, E. H., Hundeshagen, H., Kirsten, E., Kirsten, R., and Barthelmai, W.: Über den Cystin-metabolismus bei de Cystinose. Klin. Wochschr., 20: 999 (1964).

18. Lowry, O. H., Rosebrough, N. J., Farr, A. L., and Randall, R. J.: Protein measurement with the Folin phenol reagent. J. Biol. Chem., 193: 265 (1951)

19. McKusick, V. A., Neufeld, E. and Kelly, T. E.: The mucopolysaccharide storage diseases. In: J. B. Stanbury, J. B. Wyngaarden, and D. S. Fredrickson: The Metabolic Basis of Inherited Disease, 4th Edition, pp. 1282-1307 (McGraw Hill Book Co., New York, 1978).

20. Neufeld, E. F.: The biochemical basis for mucopolysaccharidoses and mucolipidoses. Prog. Med. Genet., 10: 81 (1974).

21. Oshima, R. G., Willis, R. C., Furlong, C. E., and Schneider, J. A.: Binding assays for amino acids: the utilization of a cystine binding protein from Escherichio coli for the determination of acid-soluble cystine in small physiological samples. J. Biol. Chem., 249: 6033 (1974).

22. Sando, G. N., and Neufeld, E. F.: Recognition and receptor-mediated uptake of a lysosomal enzyme, $\alpha$-L-iduronidase, by cultured human fibroblasts. Cell, 12 : 619 (1977).

23. Schneider, J. A., Schulman, J. D., and Seegmiller, J. E.: Cystinosis and the Fanconi syndrome. In: J. B. Stanbury, J. B. Wyngaarden, and D. S. Fredrickson: The Metabolic Basis of Inherited Disease, 4th Edition, pp. 1660-1682 (McGraw Hill Book Co., New York, 1978).

24. Schulman, J. D. (Ed.): Cystinosis. Department of Health, Education and Welfare Publication No. (National Institutes of Health) 72-249. United States Government Printing Office, Washington, D. C. (1973).

25. Schulman, J. D., and Bradley, K. H.: The metabolism of amino acids, peptides, and disulfides in lysosomes of fibroblasts cultured from normal individuals and those with cystinosis. J. Exp. Med., 132: 1090 (1970).

26. Sensenbrenner, J. A.: Mucolipidosis Il (I-cell disease). Birth Defects, 10 (No. 12): 470 (1974).

27. Singer, T. P.: Oxidative metabolism of cysteine and cystine in animal tissues. In: D. M. Greenberg: Metabolic Pathways, Vol. 7, pp. 536-546 (Academic Press, New York, 1975)

28. States, B., Harris, D., and Segal, S.: Uptake and utilization of exogenous cystine by cystinotic and normal fibroblasts. J. Clin. Invest., 53: 1003 (1974).

29. Stein, H., Berman, E. R., Livni, N., Merin, S., Sheskin, J., and Cohen, T.: PseudoHurler polydystrophy (mucolipidosis III): a clinical, biochemical and ultrastructural study. Israel J. Med. Sci., 10: 463 (1974).

30. Strecker, G., and Michalski, J. C.: Biochemical basis of six different types of sialidoses. FEBS Lett., 85: 20 (1978).

31. Thomas, G. H., Taylor, H. A., Reynolds, L. W., and Miller, C. S.: Mucolipidosis III (pseudo-Hurler polydystrophy): Multiple lysosomal enzyme abnormalities in serum and cultured fibroblast cells. Pediatr. Res.. 7: 751 (1973).

32. Thomas, G. H. Tiller, G. E., Reynolds, L. W., Miller, C. S., and Bace, J. W.: Increased levels of sialic acid associated with a sialidase deficiency in I-cell disease (mucolipidosis II) fibroblasts. Biochem. Biophys. Res. Commun., 7 I 188 (1976).

33. Tietze, F.: Elevated cystine levels in I-cell fibroblasts. Pediatr. Res., 10: 372 (1976).

34. Tietze, F., Bradley, K. H., and Schulman, J. D.: Enzymic reduction of cystine by subcellular fractions of cultured and peripheral leukocytes from normal and cystinotic individuals. Pediatr. Res., 6: 649-658 (1972).

35. Vladutiu, G. D., and Rattazzi, M. C.: Abnormal lysosomal hydrolases excreted by cultured fibroblasts in I-cell disease (mucolipidosis II). Biochem. Biophys. Res. Commun., 67: 956 (1975).

36. Wenger, D. A.. Sattler, M., Clark. C., and Wharton. C.: I-cell disease: Activities of lysosomal enzymes towards natural and synthetic substrates. Life Sci., 19 . 413 (1976).

37. Wiesmann, U. N., and Herschkowitz. N. N.: Studies on the pathogenetic mechanism of I-cell disease in cultured fibroblasts. Pediatr. Res., 8: 865 (1974).

38. Wiesmann, U., Vassella. F., and Herschkowitz. N.: I-cell disease: Leakage of lysosomal enzymes into extracellular fluids. N. Engl. J. Med.. 285: 1090 (1971).

39. Wiesmann. U. N., Vassella. F., and Herschkowitz. N. N.: Mucolipidosis II (I-cell disease): A clinical and biochemical study. Acta Paediatr. Scand.. 63: 9 (1974).

40. The authors thank Dr. Elizabeth Neufeld for placing these protocols at our disposal before publication.

41. The authors acknowledge with thanks the contributions of Mr. George Poy and Mr. David Towne in performing these analyses.

42. The authors thank Dr. Jerry Schneider for his generous donation of purified $E$. coli cystine-binding protein for use in these assays.

43. The authors appreciate the continued interest shown in our work by Dr. Elizabeth F. Neufeld and Dr. Joseph D. Schulman. Thanks are due also to Dr. Arthur E. Greene of the Genetic Mutant Cell Repository for much useful information relating to a number of the mutant cell cultures used in this investigation.

44. Requests for reprints should be addressed to: Frank Tietze, Ph.D., National Institutes of Health, Building 10, Room 9B-12, Bethesda, MD 20014, USA. 45. Received for publication September 19,1978

46. Accepted for publication January 8, 1979. 